\title{
SEJARAH ANTROPOLOGI HUKUM
}

\author{
Nama: Dithio Rizky Alrianda \\ No.BP : 2010003600242 \\ Kelas : $1 \mathrm{H} 9$ \\ Universitas EkaSakti Padang
}

\author{
PENDAHULUAN
}

\section{Latar Belakang}

Antropologi Hukum merupakan salah satu mata kuliah di Fakultas Hukum. Antropologi Hukum sendiri terdiri dari dua kata yaitu Antropologi dan Hukum. Kata Antropologi secara etimologis berasal dari bahasa Yunani yaitu Anthropos yang berarti manusia dan logos berarti ilmu pengetahuan. Jadi, antropologi adalah ilmu yang mempelajari tentang manusia. Sedangkan hukum merupakan suatu aturan, norma atau kaidah yang mengatur dan menjadi pedoman tingkah laku manusia. Sehingga dapat dikatakan bahwa antropologi hukum merupakan ilmu yang mempelajari mengenai peran, status atau kedudukan, nilai, norma dan juga budaya atau kebudayaan manusia. Kesemuanya ini merupakan bahan kajian dan merupakan hal yang sangat erat dalam mempelajari antropologi hukum.

Sejak warsa 1980-an dunia pendidikan ilmu hukum di Indonesia semakin diperkaya dengan pengenalan studi-studi hukum empiris dengan menggunakan pendekatan antropologis. Untuk ini, T.O. Ihromi dan Valerine J.L. Kriekhoff dari UI bekerjasama dengan F. von Benda-Beckmann dari Wageningen Agriculture University the Netherlands dapat dinobatkan sebagai peletak dasar studi-studi 
antropologis tentang hukum yang kemudian dikenal sebagai antropologi hukum (anthropology of law, legal anthropology, anthropological study of law).

Antropologi hukum pada dasarnya adalah sub disiplin ilmu hukum empiris yang memusatkan perhatiannya pada studi-studi hukum dengan menggunakan pendekatan antropologis. Kendati demikian, dari sudut pandang antropologi, sub disiplin antropologi budaya yang memfokuskan kajiannya pada fenomena empiris kehidupan hukum dalam masyarakat secara luas dikenal sebagai antropologi hukum.

Antropologi hukum pada dasarnya mempelajari hubungan timbal-balik antara hukum dengan fenomena-fenomena sosial secara empiris dalam kehidupan masyarakat, bagaimana hukum berfungsi dalam kehidupan masyarakat, atau bagaimana hukum bekerja sebagai alat pengendalian sosial (social control) atau sarana untuk menjaga keteraturan sosial (social order) dalam masyarakat. Dengan kata lain, studi-studi antropologis mengenai hukum memberi perhatian pada segi-segi kebudayaan manusia yang berkaitan dengan fenomena hukum dalam fungsinya sebagai sarana menjaga keteraturan sosial atau alat pengendalian sosial (Pospisil, 1971:x, 1973:538; Ihromi, 1989:8).Karena itu, studi antropologis mengenai hukum secara khusus mempelajari proses-proses sosial di mana pengaturan mengenai hak dan kewajiban warga masyarakat diciptakan, dirobah, dimanipulasi, diinterpretasi, dan diimplementasikan oleh warga masyarakat (F. von Benda-Beckmann, 1979, 1986).

Dari penjelasan tersebut kita dapat menyimpulkan bahwa betapa pentingnya mempelajari ilmu antropologi hukum sebagai ilmu yang mempelajari tentang bagaimana norma-norma hukum itu diimplementasikan di dalam kehidupan sosial masyarakat sehingga dalam makalah ini mencoba untuk memberi pemahaman mengenai bagaimana perkembangan antropologi Hukum dalam dunia pendidikan. 


\section{Rumusan Masalah}

Bagaimanakah sejarah perkembangan antropologi hukum sebagai salah satu sub disiplin ilmu hukum empiris yang memusatkan perhatiannya pada studi-studi hukum dengan menggunakan pendekatan antropologis dalam dunia pendidikan?

\section{Manfaat dan Tujuan}

Manfaat dan tujuan dari penyususnan makalah tentang sejarah perkembangan ilmu antropologi hukum ini antara lain : pertama untuk penyusun, sebagai salah satu sarana untuk mengetahui secara jelas mengenai sejarah perkembangan ilmu antropologi hukum dan sebagai sarana untuk memenuhi tugas mata kuliah antropologi hukum. Kemudian untuk pembaca, makalah ini sebagai referensi untuk mrngkaji lebih dalam mengenai sejarah perkembangan antropologi hukum di dunia pendidikan.

\section{PEMBAHASAN}

\section{Fase awal studi teoritis mengenai hukum dengan pendekatan antropologis.}

Awal pemikiran antropologis tentang hukum pada kenyataannya dimulai dengan studi-studi yang dilakukan oleh kalangan ahli antropologi dan bukan dari kalangan sarjana hukum. Awal kelahiran antropologi hukum biasanya dikaitkan dengan karya klasik Sir Henry Maine yang bertajuk The Ancient Law yang diterbitkan pertama kali pada tahun 1861. Ia dipandang sebagai peletak dasar studi antropologis tentang hukum melalui introduksi teori evolusionistik (the evolusionistic theory) mengenai masyarakat dan hukum, yang secara ringkas menyatakan bahwa: 
hukum berkembang seiring dan sejalan dengan perkembangan masyarakat, dari masyarakat yang sederhana (primitive), tradisional, dan kesukuan (tribal) ke masyarakat yang kompleks dan modern, dan hukum yang inherent dengan masyarakat semula menekankan pada status kemudian wujudnya berkembang ke bentuk kontrak (Nader, 1965; Roberts, 1979; Krygier, 1980; Snyder, 1981).

Tema kajian pada fase awal ini difokuskan pada fenomena hukum dalam masyarakat yang bersahaja (primitive), tradisional (traditional), dan kesukuan (tribal) dalam skala evolusi bentuk-bentuk organisasi sosial dan hukum yang mengiringi perkembangan masyarakat manusia. Sedangkan, metode kajian yang digunakan untuk memahami fenomena hukum dalam masyarakat adalah apa yang dikenal sebagai armchair methodology, yaitu metodologi untuk memahami hukum dalam perkembangan masyarakat melalui kajian-kajian yang dilakukan di belakang meja, sambil duduk di kursi empuk, dalam ruangan yang nyaman, dengan membaca dan menganalisis sebanyak mungkin documentary data yang bersumber dari catatan-catatan perjalanan para petualang atau pelancong, dari laporan-laporan berkala dan dokumen resmi para missionaris, pegawai sipil maupun para serdadu pemerintah kolonial dari daerah-daerah jajahannya (F. von Benda-Beckmann, 1989).

\section{Fase pada abad ke-20}

Pada awal abad ke-20 metode kajian hukum seperti yang dilakukan pada fase awal mulai ditinggalkan, dan mulai memasuki perkembangan metode studi lapangan (fieldwork methodology) dalam studi-studi antropologis tentang hukum. Karya Barton, misalnya, yang berjudul Ifugao Law yang dipublikasikan pertama kali pada tahun 1919 merupakan hasil dari fieldwork yang intensif dalam masyarakat suku 
Ifugao di Pulau Luzon Philipina. Kemudian, muncul karya Malinowski berjudul Crime and Custom in Savage Society yang pertama kali dipublikasikan pada tahun 1926 adalah hasil studi lapangan yang komprehensif dalam masyarakat suku Trobrian di kawasan Lautan Pasific, dan seterusnya sampai sekarang metode fieldwork menjadi metode khas dalam studi-studi antropologi hukum. Tema-tema kajian yang dominan pada fase awal perkembangan antropologi hukum berkisar pada pertanyaan-pertanyaan : apakah hukum itu ? apakah ada hukum dalam masyarakat yang bersahaja, tradisional, dan kesukuan ?; bagaimanakah hukum bewrujud dan beroperasi dalam kehidupan masyarakat?

\section{Fase pada dekade tahun 1940-an sampai dengan 1950-an}

Pada dekade tahun 1940-an sampai 1950-an tema-tema kajian antropologi hukum mulai bergeser ke mekanisme-mekanisme penyelesaian sengketa dalam masyarakat sederhana. Karya klasik dari Llewellyn dan Hoebel bertajuk The Cheyenne Way (1941) merupakan hasil studi lapangan kolaborasi dari seorang sarjana hukum dengan ahli antropologi dalam masyarakat suku Cheyenne (suku Indian) di Amerika Serikat. Kemudian, Hoebel mempublikasikan The Law of Primitive Man (1954), disusul dengan karya Gluckman mengenai hukum orang Barotse dan Lozi di Afrika, karya Bohannan mengenai hukum orang Tiv, karya Gulliver mengenai hukum orang Arusha dan Ndendeuli, karya Fallers mengenai hukum dalam masyarakat suku Soga, dan karya Pospisil tentang hukum orang Kapauku di Papua. Fase perkembangan tema studi antropologi hukum ke arah mekanisme-mekanisme peneyelesaian sengketa seperti ini disebut oleh F. von Benda-Beckmann (1989) sebagai fase the anthropology of dispute settlements. 


\section{Fase pada dekade tahun 1960-an}

Pada dekade tahun 1960-an tema studi-studi antropologi lebih memberi perhatian pada fenomena kemajemukan hukum atau pluralisme hukum. Tema pluralisme hukum pertama-tama difokuskan pada kemajemukan cara-cara penyelesaian melalui mekanisme tradisional, tetapi kemudian diarahkan kepada mekanisme dan institusi penyelesaian sengketa menurut hukum pemerintah kolonial dan pemerintah negara-negara yang sudah merdeka. Karya Bohannan, Gluckman, dan Gulliver misalnya, tidak secara sistematis memberi perhatian pada eksistensi mekanisme dan institusi penyelesaian sengketa menurut hukum kolonial dan hukum negara-negara sedang berkembang.

\section{Fase pada dekade 1970 -an}

Sejak tahun 1970-an tema studi-studi antropologi hukum secara sistematis difokuskan pada hubungan antar institusi-institusi penyelesaian sengketa secara tradisional, neo-tradisional, dan menurut institusi hukum negara. Karya Nader dan Todd (1978) misalnya, memfokuskan kajiannya pada proses, mekanisme, dan institusi-institusi penyelesaian sengketa di komunitas masyarakat tradisional dan modern di beberapa negara di dunia, melalui Berkeley Village Law Projects, menjadi karya yang memperlihatkan kecenderungan baru dari topik-topik studi antropologi hukum. Publikasi lain yang perlu dicatat adalah mekanisme penyelesaian sengketa di kalangan orang Togo di Afrika karya van Rouveroy van Nieuwaal, kemudian karya F. von Benda-Beckmann (1979) dan K. von Benda-Beckmann (1984) yang memberi pemahaman tentang penyelesaian sengketa harta warisan di kalangan orang Minangkabau menurut pengadilan adat dan di pengadilan negeri di Sumatera Barat. Fase selanjutnya studi pluralisme mekanisme penyelesaian sengketa mulai ditinggalkan, dan mulai diarahkan kepada studi-studi pluralisme hukum di luar 
penyelesaian sengketa. Karya Sally F. Moore (1978) misalnya, mengenai kemajemukan hukum agraris dalam kehidupan suku Kilimanjaro di Afrika, dan mekanisme dalam proses produksi pabrik garment terkenal di Amerika dapat dicatat sebagai perkembangan baru studi pluralisme hukum. Kemudian, studi-studi pluralisme hukum mulai difokuskan pada mekanisme jaminan sosial (social security), pasar dan perdagangan, mekanisme irigasi pertanian, institusi koperasi dan perkreditan di daerah pedesaan di negara-negara sedang berkembang. Studi-studi ini dikembangkan oleh Agrarian Law Department Wageningen Agriculture University. Fase perkembangan tema pluralisme hukum yang menyoroti topik-topik penyelesaian sengketa maupun non penyelesaian sengketa, interaksi antara hukum negara, hukum rakyat, atau dengan hukum agama disebut oleh F. von Benda-Beckmann (1989) sebagai fase the anthropology of legal pluralism. Kecenderungan yang berkembang sejak tahun 1970-an adalah penggunaan pendekatan sejarah dalam studi-studi antropologi hukum. Studi yang dilakukan Moore (1986), Snyder (1981), F. von Benda-Beckmann (1979), K. von Benda- Beckmann (1984) misalnya, secara eksplisit menggunakan kombinasi dimensi sejarah untuk menjelaskan interaksi institusi hukum negara (state law) dengan hukum rakyat (folk law) dalam kajian pluralisme hukum penyelesaian sengketa..

\section{PENUTUP}

\section{Kesimpulan}

Dari penjelasan mengenai sejarah perkembangan ilmu antropologi hukum tersebut, dapat disimpulkan bahwa ilmu antropologi hukum pada dasarnya adalah sub disiplin ilmu hukum empiris yang memusatkan perhatiannya pada studi-studi 
hukum dengan menggunakan pendekatan antropologis. Pada fase awal perkembangan antropologi hukum pendapat yang sangat dominan disini adalah yang menyatakan bahwa hukum itu berkembang sejalan dengan perkembangan hidup masyarakat. Kemudian pada abad ke-20, kajian ilmu antropologi hukum masih sebatas pada hal yang sederhana seperti pengenalan hukum. Fase selanjutnya perkembangan antropologi hukum telah mengkaji mengenai kemajemukan atau pluralisme hukum dalam masyarakat. Dan pada fase terakhir kajian ilmu antropologi hukum telah mencapai suatu peningkatan yaitu mulai mengkaji mengenai penyelesaian sengketa yang terjadi di dalam masyarakat yang tentunya berdasarkan pada metode antropologi hukum baik secara tradisional, neo-tradisional, maupun dengan menggunakan hukum negara.

\section{Saran}

Aspek penjelasan mengenai perkembangan ilmu antropologi hukum yang tercantum dalam makalah ini hanyalah sebagian kecil dari bahasan pokok yang terdapat dalam sumber-sumber seperti buku bacaan. Masih banyak aspek lain yang dapat menunjang dalam peningkatan pengetahuan mengenai sejarah perkembangan ilmu antropologi hukum. Oleh karena itu penulis mengharapkan pengkajian materi yang terkait dengan isi dalam makalah ini agar terus ditingkatkan.

\section{DAFTAR PUSTAKA}

Gokma Toni Parlindungan S, Asas Nebis In Idem Dalam Putusan Hakim Dalam Perkara Poligami Di Pengadilan Negeri Pasaman Sebagai Ceriminan Ius Constitutum, Volume 2, Nomor 1, 2020. 
Harniwati, Peralihan Hak Ulayat Menurut Undang-Undang Nomor 18 Tahun 2004, Volume 1, Nomor 3, 2019.

Jasmir, Pengembalian Status Hukum Tanah Ulayat Atas Hak Guna Usaha, Soumatera Law Review, Volume 1, Nomor 1, 2018.

Jumrawarsi Jumrawarsi, Neviyarni Suhaili, Peran Seorang Guru Dalam Menciptakan Lingkungan Belajar Yang Kondusif, Ensikopedia Education Review, Vol 2, No 3 (2020): Volume 2 No.3 Desember 2020

Mia Siratni, Proses Perkawinan Menurut Hukum Adatdi Kepulauan Mentawai Di Sebelum Dan Sesudah Berlakunya Undang-Undang Nomor 1 Tahun 1974 Tentang Perkawinan, Ensiklopedia Of Journal, Vol 1 No 2 Edisi 2 Januari 2019,

Remincel, Dimensi Hukum Pelanggaran Kecelakaan Lalu Dan Angkutan Jalan Lintas Di Indonesia, Ensiklopedia Social Review, Volume 1, Nomor 2, 2019.

R Amin, B Nurdin, Konflik Perwakafan Tanah Muhammadiyah di Nagari Singkarak Kabupaten Solok Indonesia 2015-2019, Soumatera Law Review, Volume 3, Nomor 1, 2020. 